\title{
Constraints in Production and Marketing of Vegetables in Udhampur District of Jammu and Kashmir Union Territory
}

\author{
Anil Bhat*, Jyoti Kachroo, Sudhakar Dwivedi, S.P. Singh and Malika Sharma \\ Division of Agricultural Economics and Agribusiness Management \\ Sher-e-Kashmir University of Agricultural Sciences and Technology of Jammu
}

"Corresponding author: drbhatanil@gmail.com

Received: 14 Sept., 2020

Revised: 17 Nov., 2020

Accepted: 11 Dec., 2020

\begin{abstract}
Demand for vegetables has increased many fold for the last few years as people are now health conscious and are consuming vegetables regularly for getting health benefits as well. These vegetables are grown on high scale in various belts of Udhampur district. The present study was conducted in Chenani block of Udhampur district as the selected area is hub of quality vegetable production. Four vegetable growing villages were selected randomly and from each village 20 farmers were selected randomly to constitute a sample of 80 farmers in all. The results of the study revealed that the most of the respondents were facing the problem of lack of irrigation facilities, high labour cost and non-availability of labour during peak period. Low prices of agricultural goods, pest disease insect problem, drought and lack of credit facilities were other problems faced by the farmers. Few of the farmers were of the opinion that latest technical knowledge and availability of good quality seedlings in sufficient quantity is lacking in the area. High cost of pesticides was the other production problem. Farmers of Bashat area in particular were facing a specific problem that is road connectivity from their fields to roadside. The fields were not well connected to the road and the link was in dilapidated conditions which force them to transport the produce through human labour which in turn increases their marketing cost resulting in decline in their profit.
\end{abstract}

Keywords: Constraints, production, marketing, vegetables

The economic aspects of vegetable cultivation are not less important as well maintained and established fields give better returns than cereal crops from the same piece of land. It may also be mentioned that there are many factors which may enhance the production of vegetables but among them cost and return coupled with marketing are considered being the key factors for increasing the production. The growers before prioritizing the preferences for vegetable cultivation ensures its cost and return factor, which

is the main motivation factor for bringing more area vis-à-vis giving lot of attention. Moreover, along with the production, the role of marketing opportunities are equally important, as the farmers can ensure the reasonable return for their produce and also a legitimate share in the price paid by the consumers. Although area under fruits and vegetables and its production has shown a steady increase over time, yet their marketing aspects (comprising of marketing cost, marketing margin,

How to cite this article: Bhat, A., Kachroo, J., Dwivedi, S., Singh, S.P. and Sharma, M. (2020). Constraints in Production and Marketing of Vegetables in Udhampur District of Jammu and Kashmir Union Territory. International Journal of Inclusive Development, 6(02): 77-79.

Source of Support: None; Conflict of Interest: None $\infty$ 
marketing loss and price spread) has all along been almost neglected and at present marketing facilities are inadequate. Under the existing marketing practice, before the produce reaches to the end user, it has to be handled and passed through a long chain of various intermediaries, with the result that the producers are getting a small share of consumers' rupee and they have to face number of production and marketing problems. Therefore, identifying problems associated with production and marketing of vegetables provides an opportunity to know the actual position of farmers while producing and marketing vegetables. The difference between the price received by the farmer and price paid by the consumer comprises cost of undertaking and rendering market services such as assembling, grading, transporting, processing, wholesaling, retailing and the margins of the intermediaries, charges, sale tax etc, as they are too wide because to its perishable nature, seasonality of production, spatial distribution of plantation far off from consuming centres, inadequate cold storage and credit facilities and lack of comprehensive marketing information. All these forces compel the growers to sell their produce unprocessed and immediately after harvest, resulting gluts in the markets and thereby fall in prices and hence lower returns.

\section{MATERIALS AND METHODS}

The present study was conducted in Chenani block of Udhampur district as the selected area is hub of quality vegetable production. Four vegetable growing villages were selected randomly and from each village 20 farmers were selected randomly to constitute a sample of 80 farmers in all. The information about the problems faced by the vegetable growers were ascertained from the selected respondents on various aspects of production and marketing.

Tabular and percentage analysis was done to find out the result of proposed objectives:

1. Tabular analysis: This approach was used for the analysis of the production and marketing constraints of vegetable growers. Frequency of the respondents experiencing problems were tabulated, computed and analyzed using percentage analysis.

\section{Percentage analysis}

Percentage refers to a special kind of ratio. It is used to make comparison between two or more series of data. They can be used to compare the relative items, the distribution of two or more series of data, since the percentage reduces everything to a common base and there by allow meaningful comparisons to be made. In the present study the percentage analyses helped to check the relative comparison of major problems in terms of percentage.

$$
\text { Percentage }=X / Y \times 100
$$

Where, $X$ and $Y$ differ according to the objectives of the study.

\section{RESULTS AND DISCUSSION}

The major problems faced by the farmers in the production of vegetables are presented in Table 1 which revealed that 90.00 per cent of the respondents were facing high labour cost as a major problem followed by non-availability of labour during peak $(85.00 \%)$, low prices of vegetables $(80.00 \%)$, problem of attack of insect, pest and disease $(75.00 \%)$. Drought and lack of credit facilities were other problems faced by the farmers. Few of the farmers were of the opinion that latest technical knowledge and availability of good quality seedlings in sufficient quantity is lacking in the area. High cost of pesticides was the other production problem as reported by 67.50 percent of the farmers. More than 50 per cent of the farmers were also facing the problem of lack of irrigation facilities. These results are in conformity with the Shah et al. (2020).

Table 1: Production constraints faced by Vegetable growers of Udhampur district

\begin{tabular}{llcc}
\hline S1. & \multirow{2}{*}{ No. } & \multicolumn{2}{c}{ Respondents (N=80) } \\
\cline { 2 - 4 } & Frequency & Percentage \\
\hline 1 & High labour cost & 72 & 90.00 \\
2 & $\begin{array}{l}\text { Non-availability of labour } \\
\text { during peak }\end{array}$ & 68 & 85.00 \\
3 & Low prices of vegetables & 64 & 80.00 \\
4 & $\begin{array}{l}\text { Problem of attack of insect, } \\
\text { pest and disease }\end{array}$ & 60 & 75.00 \\
5 & Drought and lack of credit & 60 & 75.00 \\
& facilities & 54 & 67.50
\end{tabular}


$7 \quad$ Inadequate latest technical knowledge and availability of good quality seedlings in sufficient quantity 52 46 44

9 High cost of seed 60 fruit plants

Marketing constraints faced by vegetable growers of Udhampur district are presented in Table 2. The results of the study revealed that 80.00 per cent of the respondents farmers particularly of Bashat area were facing a specific problem that is road connectivity from their fields to roadside. The fields were not well connected to the road and the link was in dilapidated conditions which force them to transport the produce through human labour which in turn increases their marketing cost resulting in decline in their profit.

Table 2: Marketing constraints faced by Vegetable growers of Udhampur district

\begin{tabular}{|c|c|c|c|}
\hline \multirow{2}{*}{$\begin{array}{l}\text { Sl. } \\
\text { No. }\end{array}$} & \multirow{2}{*}{ Problems } & \multicolumn{2}{|c|}{ Respondents $(\mathrm{N}=80)$} \\
\hline & & Frequency & Percentage \\
\hline 1 & $\begin{array}{l}\text { Long distance from the } \\
\text { production point to market }\end{array}$ & 74 & 92.50 \\
\hline 2 & High transportation cost & 72 & 90.00 \\
\hline 3 & High cost of labour & 70 & 87.50 \\
\hline 4 & $\begin{array}{l}\text { Non-availability of market in } \\
\text { close vicinity }\end{array}$ & 70 & 87.50 \\
\hline 5 & $\begin{array}{l}\text { Not getting remunerative of } \\
\text { the produce }\end{array}$ & 63 & 78.75 \\
\hline 6 & $\begin{array}{l}\text { High commission charged by } \\
\text { Market Intermediaries }\end{array}$ & 60 & 75.00 \\
\hline 7 & Fluctuation in prices & 55 & 68.75 \\
\hline 8 & $\begin{array}{l}\text { Inadequate road connectivity } \\
\text { from their fields to roadside }\end{array}$ & 54 & 67.50 \\
\hline 9 & Lack of market information & 50 & 62.50 \\
\hline
\end{tabular}

Long distance from the production point to market, high transportation cost and high cost of labour were major problem reported by 92.50 per cent, 90.00 per cent and 87.50 per cent of the farmers, respectively. Non-availability of market in the close vicinity (87.50 per cent), not getting remunerative of the produce (78.75 per cent) and high commission charged by the forwarding agents (75.00 per cent) were the other main marketing problems reported by the respondents. It was cumbersome and little bit difficult for them to market the produce to Jammu or Udhampur.

Fluctuation in prices and lack of market information were other marketing problems reported in the study area. The results are in close conformity with and Kumari (2017) in their respective studies.

\section{CONCLUSION}

The major problems faced by the vegetable growers in production and marketing identified and majority of the farmers put high labour cost as major problem faced during production of commodities. There were other problems which also create hurdles for vegetable growers in cultivation of crops and these were attack of insect and pests, high cost of seed, lack of irrigation facilities, inadequate latest technical knowledge and availability of good quality seedlings in sufficient quantity. Marketing constraints such as long distance from the production point to market, non-availability of market in close vicinity and high commission charged by Market Intermediaries are few marketing problems which are directly related with the functioning of the market which needs to be improved.

\section{REFERENCES}

Acharya, S.S. and Aggarwal, N.L. 2001. Agricultural Marketing in India. Third edition, Oxford \& IBH Publishing Company, New Delhi.

Ghafoor, U., Muhammad, S., Chaudhary, K.M., Mahmood, A. R. and Ashraf, I. 2010. Harvesting and marketing problems faced by citrus (kinnow) growers of tehsil Toba Tek Singh. Journal of Agricultural Research, 48(2): 253-257.

Kumari, M. 2017. Estimation of demand supply gap and major constraints in production and marketing of major fruits and vegetables in Bihar, India. International Journal of Current Microbiology and Applied Sciences, 6(6): 2662-2672.

Shah, P. and Ansari, M.A. 2020. A Study of Marketing and Production Constraints Faced by Vegetable Growers. Asian Journal of Agricultural Extension Economics $\mathcal{E}$ Sociology, 38(11): 257-263. 
